\title{
NORMATYWNE A EKONOMICZNE UJĘCIE REGULACJI EKOLOGICZNYCH, ZE SZCZEGÓLNYM UWZGLĘDNIENIEM ROLI GRUP INTERESU W ICH KSZTAKTOWANIU
}

\section{WSTĘP}

Szybki rozwój gospodarczy, zwłaszcza w XX wieku, spowodował powstanie wielu negatywnych zjawisk środowiskowych, takich jak: zanieczyszczenie i degradacja środowiska przyrodniczego, nieodwracalne zmiany w ekosystemach, pogorszenie się jakości życia ludzi, wyczerpywanie się zasobów naturalnych. Jednocześnie rosną społeczne oczekiwania dotyczące jakości środowiska przyrodniczego jako przestrzeni, w której żyjemy i prowadzimy działalność gospodarczą. Od kilkudziesięciu lat problemy związane $z$ użytkowaniem i ochroną środowiska przyrodniczego są badane i dyskutowane nie tylko w ujęciu statycznym (korzystania ze środowiska obecnie), ale również w ujęciu dynamicznym, a więc z punktu widzenia odpowiedzialności międzypokoleniowej ${ }^{1}$. Działalność gospodarcza człowieka, zarówno produkcyjna, jak i konsumpcja, odbywa się w środowisku przyrodniczym, przy korzystaniu z jego zasobów, a rynek nie generuje mechanizmów, które by zapobiegały lub ograniczały negatywne konsekwencje tej działalności, zarówno w odniesieniu do skali gospodarczego korzystania z zasobów środowiska, jak i gwarancji wysokiej jakość korzyści pozaekonomicznych czerpanych przez ludzi ze środowiska przyrodniczego.

Narastające problemy w sferze gospodarczego użytkowania środowiska przyrodniczego wymusiły konieczność aktywnych działań państwa w zakresie jego ochrony i gospodarowania zasobami przyrodniczymi. Według W. F. Samuelsona i S. G. Marksa mikroekonomiczna rola państwa sprowadza się, przede wszystkim, do spełnienia dwóch zasadniczych funkcji: 1) regulowania prywatnych rynków

${ }^{1}$ Problemy sprawiedliwości międzypokoleniowej oraz skali korzystania z dóbr i usług środowiska przyrodniczego zostały szeroko omówione w literaturze poświęconej koncepcji zrównoważonego i trwałego rozwoju. 
tam, gdzie niedoskonałość rynku może stać się przyczyną nieefektywnej produkcji lub/i konsumpcji; 2) udostępnianie „właściwej” ilości pewnych dóbr i usług publicznych, których rynki prywatne nie dostarczają w ogóle lub nie są w stanie dostarczyć w odpowiedniej ilości². Według D. Spulbera „Regulacja publiczna działalności gospodarczej to ogólne zasady lub specyficzne działania agend rządowych i innych podmiotów administracji publicznej, które oddziałują bezpośrednio na mechanizm alokacyjny rynku poprzez wpływ na decyzje producentów i konsumentów dotyczące podaży i popytu” ${ }^{3}$. W niniejszym artykule rozważania zostaną ograniczone do kształtowania się regulacji dotyczących ochrony środowiska przyrodniczego, a zatem do regulacji ekologicznych.

Celem artykułu jest próba ukazania roli grup interesu w kształtowaniu się regulacji ekologicznych w gospodarce rynkowej w świetle teorii regulacji normatywnej i ekonomicznej w odniesieniu do sfery ochrony i użytkowania środowiska przyrodniczego.

Ze względu na rozmiary opracowania przedstawione rozważania nie wyczerpują całości zagadnienia, są jedynie zasygnalizowaniem problemów. Jako takie, wymagają dalszych studiów i badań.

\section{PRZYCZYNY I CELE REGULACJI EKOLOGICZNYCH ORAZ NARZĘDZIA OSIĄGANIA TYCH CELÓW}

W literaturze ekonomicznej działalność regulacyjną państwa uzasadnia się koniecznością korygowania niedoskonałej koordynacji mechanizmu rynkowego, dotyczy to również obszaru użytkowania środowiska przyrodniczego i gospodarowania jego zasobami. Punktem wyjścia jest powszechnie znane stwierdzenie, że w praktyce nie jest możliwe osiągnięcie optimum ogólnego w sensie Pareto. Realne gospodarki rynkowe charakteryzują się występowaniem wielu niedoskonałości rynku (błędów, zawodności rynku), które uniemożliwiają osiąnnięcie efektywności alokacyjnej, równowagi rynkowej oraz maksymalizacji dobrobytu społecznego. Ponieważ niedoskonałości mechanizmu rynkowego i ich negatywne następstwa dotyczą również sfery użytkowania, ochrony i zanieczyszczania środowiska przyrodniczego, uznaje się konieczność regulacji ekologicznych. Rynek nie

${ }^{2}$ W. F. Samuelson, S. G. Marks, Managerial Economics, wyd. polskie: Ekonomia menedżerska, PWE, Warszawa 1998, s. 598-599.

${ }^{3}$ D. Spulber, Regulation and Markets. Massachussetts Institute of Technology, Cambridge MA 1989; podaję za: B. Fiedor, Normatywne a ekonomiczne ujęcie regulacji publicznej w gospodarce rynkowej, z uwagami dotyczacymi sektora elektroenergetycznego, [w:] Dokonania wspótczesnej myśli ekonomicznej. Ekonomia instytucjonalna - teoria i praktyka, red. U.Zagóra-Jonszta, Wyd. AE w Katowicach, Katowice 2006, s. 219. W literaturze przedmiotu można znaleźć wiele różnych definicji regulacji, często przywołuje się definicje G. Stiglera i T. Kahna. 
jest w stanie wygenerować mechanizmów, które gwarantowałyby, że skala i sposób korzystania ze środowiska przyrodniczego i jego zasobów będą odpowiadały preferencjom społecznym, zwłaszcza w odniesieniu do okresu długiego. Natomiast poziom dobrobytu społecznego, a jeszcze bardziej dobrostanu, zależy, między innymi, zarówno od korzyści ekonomicznych, jak i usług pozaekonomicznych dostarczanych przez środowisko przyrodnicze. Problem ten nabiera ostrzejszego wymiaru w kontekście przyjęcia przez wiele państw gospodarki rynkowej koncepcji zrównoważonego rozwoju. Aktywna rola państwa w obszarze środowiska przyrodniczego i gospodarowania zasobami przyrodniczymi znajduje swój wyraz w polityce ekologicznej i regulacjach ekologicznych.

Polityka ekologiczna jest świadomą i celową działalnością państwa, władz publicznych różnego stopnia $\mathrm{w}$ zakresie gospodarowania środowiskiem, czyli użytkowania jego zasobów i walorów, ochrony i kształtowania ekosystemów lub wybranych elementów biosfery. Przedmiotem polityki ekologicznej jest środowisko przyrodnicze i jego jakość oceniana z punktu widzenia potrzeb ludzi: biologicznych, społecznych (ochrona ekosystemów, obszarów i obiektów stanowiących dziedzictwo narodowe lub zaspokajających istotne potrzeby społeczne) i gospodarczych (zapewnienie rozwoju gospodarczego i wzrostu dobrobytu społecznego) $)^{4}$.

Do podstawowych celów polityki i regulacji ekologicznych można zaliczyć5:

1) identyfikowanie i adresowanie za pomocą różnych instrumentów regulacji prawnej, administracyjnej, ekonomiczno-finansowej, przy wspomagającym wykorzystaniu metod związanych $\mathrm{z}$ oddziaływaniem na wiedzę i świadomość ekologiczną obywateli, zarówno samych niedoskonałości rynku w sferze ochrony środowiska i gospodarowania jego zasobami, jak i skutków tych niedoskonałości,

2) modyfikowanie mechanizmu rynkowego, tak aby w tym stopniu, w jakim nie zagraża to bezpieczeństwu ekologicznemu, mógł on ujawniać preferencje społeczne w zakresie pożądanego stanu jakościowego środowiska oraz funkcjonować jako metoda alokacji, w tym międzypokoleniowej, ograniczonych zasobów pomiędzy różne zastosowania służące ochronie i racjonalnemu kształtowaniu środowiska.

Osiąganiu celów polityki ekologicznej służą instrumenty regulacji ekologicznych, które można podzielić na dwie zasadnicze grupy: instrumenty regulacji bez-65 .

${ }^{4}$ K. Górka, B. Poskrobko, W. Radecki, Ochrona środowiska, PWE, Warszawa 2001, s. 64-

${ }^{5}$ B. Fiedor, A. Matysiak, Rola państwa wu ujęciu teorii trwatego rozwoju z punktu widzenia problemu międzypokoleniowej sprawiedliwości ekologicznej, [w:] U. Zagóra-Jonszta (red.), Dokonania wspótczesnej myśli ekonomicznej - teorie neoliberalne wobec ekonomicznej roli państwa a polityka spoteczno-ekonomiczna, Wyd. AE w Katowicach, Katowice 2004, s. 63. 
pośredniej, czyli administracyjno-prawnej; instrumenty regulacji pośredniej, czyli ekonomiczno-rynkowej.

Regulacje prawno-administracyjne można scharakteryzować jako nakazy lub zakazy określające sposób i intensywność korzystania z zasobów środowiska przyrodniczego. Obejmują one następujące grupy instrumentów: standardy emisji, imisji i standardy produktowe, licencje i pozwolenia prawno-administracyjne, nakazy i zakazy oraz zalecenia ekologiczne, normy technologiczne i zakazy dotyczące wyboru technologii, instrumenty związane $\mathrm{z}$ zarządzaniem ochroną środowiska i wykorzystaniem jego zasobów, a przede wszystkim: przeglądy ekologiczne, oceny oddziaływań inwestycji na środowisko, nakazy stosowania odpowiednich technologii produkcji.

Regulacje bezpośrednie są popularne w wielu systemach ochrony środowiska przyrodniczego. Przyczyny tego zjawiska są następujące: instytucje regulujące uważają je za wysoce skuteczne; cenią je grupy interesu ze względu na specyficzny, podlegający lobbingowi sposób ich wprowadzania; ponadto są bardziej czytelne dla szerokich kręgów społecznych i cieszą się społecznym uznaniem wynikającym z przekonania o ich skuteczności, a także nie są powszechnie kojarzone przez konsumentów z koniecznością partycypowania w kosztach takich rozwiązań

W większości krajów OECD system regulacji ochrony środowiska charakteryzuje się swoistą dualnością. Polega ona na tym, że w ramach tego systemu współistnieją liczne instrumenty regulacji bezpośredniej (prawno-administracyjnej) i pośredniej, czyli ekonomicznej. Mechanizmy ekonomiczne i rynkowe wykorzystywane w polityce ekologicznej uzupełniają bądź wzmacniają działanie narzędzi prawnych i administracyjnych oraz stwarzają możliwość minimalizacji społecznych kosztów ochrony środowiska (wynikających między innymi z niedoskonałości państwa jako regulatora $)^{7}$.

${ }^{6}$ Zagadnienie związane z polityką ekologiczną oraz stosowanymi w praktyce rodzajami i instrumentami regulacji w ochronie środowiska przyrodniczego i gospodarowania jego zasobami zostały szeroko opisane w literaturze przedmiotu, m.in. w: B. Fiedor, S. Czaja, A. Graczyk, Z. Jakubczyk, Podstawy ekonomii środowiska i zasobórw naturalnych, Warszawa 2002, Wyd. C. H. Beck, Warszawa 2002, s. 280-380.

${ }^{7}$ A. Graczyk, I. Rumianowska, Wptyw regulacji na ksztattowanie modeli rynku produktów ekologicznych, referat na konferencję naukową pt. „Rozwój rynków produktów ekologicznych”, AE, Wrocław 11.03.2008 r. Takie podejście do roli instrumentów ekonomicznych zostało przyjęte zarówno w Polityce Ekologicznej Państwa z roku 1991, jak i - w szczególności - II Polityce Ekologicznej Państwa z roku 2000. Patrz szeroko na ten temat: B. Fiedor, A. Graczyk, Modyfikacja mechanizmów ekonomiczno-finansowych polityki ekologicznej państwa, [w:] Nowe instrumenty polityki ekologicznej, ESEŚiZN, Biblioteka „Ekonomia i Srodowisko”, nr 28, s. 100-116. 


\section{NORMATYWNA A EKONOMICZNA TEORIA REGULACJI PUBLICZNYCH JAKO PODSTAWA BADANIA REGULACJ W OBSZARZE OCHRONY ŚRODOWISKA PRZYRODNICZEGO}

Kształtowanie się regulacji w obszarze użytkowania i ochrony środowiska przyrodniczego można badać na podstawie normatywnej teorii regulacji, dominującej w ekonomi głównego nurtu, oraz ekonomicznej teorii regulacji, rozwiniętej na gruncie koncepcji stworzonych przez nową ekonomię instytucjonalną a zwłaszcza teorię wyboru publicznego ${ }^{8}$.

Normatywna teoria regulacji opiera się na założeniu, że jej konieczność wynika z niedoskonałości rynku, dotyczy to również sfery ochrony środowiska przyrodniczego i gospodarowania jego zasobami. W ekonomii środowiska i zasobów naturalnych dominuje neoklasyczne podejście do ochrony środowiska i gospodarowania jego zasobami. W tym kontekście regulacje ekologiczne są implikowane przez zawodności rynku i niemożność stworzenia przez rynek mechanizmów prowadzących do efektywnej, w sensie optimum Pareto, alokacji zasobów przyrodniczych, co w konsekwencji prowadzi do utraty części dobrobytu społecznego.

W odniesieniu do użytkowania i ochrony środowiska przyrodniczego najistotniejszymi przesłankami dla aktywnej roli państwa są: powszechne występowanie ekologicznych efektów zewnętrznych oraz publiczny charakter znacznej części dóbr środowiska przyrodniczego, co przy niedoskonałej przejrzystości rynków nie gwarantuje efektywności alokacyjnej i bezpieczeństwa ekologicznego.

W aspekcie ekologicznym na szczególną uwagę zasługują środowiskowe efekty zewnętrzne ${ }^{9}$. Występowanie korzyści lub kosztów zewnętrznych powoduje, że cena rynkowa dóbr, odzwierciedlająca prywatne koszty produkcji dóbr, nie uwzględnia całych kosztów społecznych ich wytworzenia. Występowanie korzyści zewnętrznych powoduje, że producenci nie osiągają optymalnej ze społecznego punktu widzenia wielkości produkcji danego dobra, natomiast występowanie kosztów zewnętrznych oznacza, że podaż danego dobra jest większa od optymalnej (z punktu widzenia dobrobytu społecznego), co oznacza, że zasoby przyrodnicze są nadmiernie eksploatowane. Pojawia się tu problem internalizacji kosztów

${ }^{8} \mathrm{Na}$ temat normatywnej teorii regulacji i ekonomicznej teorii regulacji w ochronie środowiska w literaturze polskiej zob. np. B. Fiedor, Nowa ekonomia instytucjonalna a zrównoważony rozwój, [w:] B. Poskrobko (red.), Obszary badań nad trwatym i zrównoważonym rozwojem, Wyd. Ekonomia i Środowisko, Białystok 2007, s. 160-162, oraz Regulacja ekologiczna jako rodzaj regulacji publicznej w gospodarce rynkowej-ujeccie normatywne a ekonomia polityczna regulacji, „Studia Ekonomiczne" 2003, nr 4, s. 297-310.

${ }^{9}$ Szeroko na ten temat: W. J. Baumol, W. E. Oates, The Theory of Environmental Policy, Prentice-Hall, Englewood Clifs 1975, s. 17; w literaturze polskiej np. A. Graczyk, Ekologiczne koszty zewnętrzne. Identyfikacja, szacowanie, internalizacja, Wyd. Ekonomia i Środowisko, Białystok 2005, s. 12-13. 
zewnętrznych i związany z nim problem wyceny dóbr i usług środowiska przyrodniczego ${ }^{10}$ oraz konieczność stworzenia i zastosowania przez państwo określonych metod i narzędzi pozwalających na określenie pożądanej społecznie skali korzystania ze środowiska przyrodniczego. Wycena dóbr i usług środowiskowych, pomiar efektów zewnętrznych, dobór najbardziej efektywnych narzędzi polityki ekologicznej, a wreszcie rachunek kosztów i korzyści z wprowadzanych regulacji (zwłaszcza w ujęciu długookresowym) utrudniany jest przez, powszechnie występujące w praktyce gospodarczej, zjawisko niedoskonałej informacji i asymetrii informacji.

Wiele dóbr środowiska przyrodniczego to dobra publiczne i zarazem dobra wolne, a zatem charakteryzują się one zerowym kosztem alternatywnym. Wzmaga to dodatkowo tendencje do przekraczania społecznie optymalnego (maksymalizującego dobrobyt) poziomu konsumpcji czy zużycia tych dóbr. Przekraczane są również zdolności asymilacyjne środowiska przyrodniczego. Optymalizacja wymaga - podobnie jak przy przeciwdziałaniu negatywnym skutkom niekonkurencyjności w korzystaniu - regulacyjnego działania państwa polegającego na stosowaniu przymusu administracyjno-prawnego lub/i wprowadzania odpłatności za usługi środowiska przyrodniczego ${ }^{11}$. Ponadto zmiany społeczne i ekonomiczne powodują, że w stosunku do wielu dóbr środowiskowych nie są w pełni realizowane zasady niekonkurencyjności i niewykluczalności, coraz częściej występuje zjawisko zatłoczenia lub utraty przez te dobra cech czystych dóbr publicznych. Dodatkowo ma miejsce przekształcanie się tych dóbr w dobra klubowe, występowanie zjawiska "jazdy na gapę" (free-riding) oraz rodzącego wiele problemów ekonomicznych i społecznych syndromu NIMBY (Not In My Back Yard - „nie na moim podwórku”) - w odniesieniu do lokalizacji inwestycji dotyczących np. składowania i zagospodarowania odpadów. Konieczność korygowania przez państwo niedoskonałej regulacji rynkowej legła u podstaw kształtowania się w praktyce regulacji ekologicznych.

$\mathrm{Na}$ gruncie nowej ekonomii instytucjonalnej problemy związane z działaniami regulacyjnymi państwa i rolą grup interesu w ochronie środowiska przyrodniczego można badać w oparciu o teorie wyboru publicznego, teorie regulacji, przy szerokim odwołaniu się do ekonomicznych koncepcji grup interesu. Ekonomiczna teoria regulacji przyjmuje, że regulacje, również ekologiczne, są swoistym towa-

${ }^{10}$ J. T. Winppeny, Wartość środowiska. Metody wyceny ekonomicznej, PWE, Warszawa 1995; oraz B. Fiedor, Przyczynek do ekonomicznej teorii zanieczyszczenia i ochrony środowiska, PWE, Wrocław-Warszawa 1990.

${ }^{11} \mathrm{~B}$. Fiedor, Dziatania zbiorowe w sferze zanieczyszczania środowiska i jego ochrony. Próba objaśnienia na podstawie teorii dóbr publicznych i teorii niedoskonatości rynku oraz teorii regulacji publicznej w gospodarce rynkowej, [w:] Dziatania zbiorowe - teoria i praktyka, Wrocław 2003, PN AE we Wrocławiu, s. 29. 
rem, a ich kształtowanie się jest wynikiem gry pomiędzy podmiotami i grupami interesu a organami legislacyjnymi, dążącymi do maksymalizacji własnych korzyści w następstwie korzystnych dla siebie rozwiązań regulacyjnych. Odwołanie się do ekonomicznej teorii regulacji, w tym opracowaniu, jest zasadne, albowiem akcentuje się w niej rolę grup interesu w tworzeniu regulacji ekonomicznych, co stwarza możliwości do prowadzenia analiz teoretycznych i badań empirycznych dotyczących miejsca grup interesu w kształtowaniu się regulacji ekologicznych we współczesnych gospodarkach rynkowych.

Cechą wspólną wszystkich ekonomicznych teorii regulacji jest założenie konieczności wspomagania przez państwo koordynacyjnej roli rynku. Ponieważ w literaturze przedmiotu funkcjonuje wiele modeli należących do ekonomicznej teorii regulacji (np. teorie: G. Stiglera, S. Pelzmana, G. Beckera, R. Posnera $\mathrm{i}$ innych) $\mathrm{i}$ ich omówienie przekraczałoby ramy tego opracowania, zatem przedstawiona tu zostanie, za B. Fiedorem, istota tej teorii bez wnikania w szczegóły poszczególnych modeli ${ }^{12}$.

- Państwo dysponuje prawem przymusu.

- Wszyscy aktorzy życia polityczno-gospodarczego, w tym politycy, legislatorzy i funkcjonariusze instytucji regulacyjnych, postępują racjonalnie i maksymalizują swoją funkcję użyteczności.

- Politycy kierują się przede wszystkim kryterium zdobycia i/lub utrzymania władzy. Grupy interesu konkurują ze sobą, oferując im poparcie lub pieniądze na prowadzenie kampanii wyborczej. Politycy wybierają najkorzystniejsze oferty i w przypadku wygranych wyborów oferują im oczekiwane regulacje.

- Dla producentów regulacje są zazwyczaj bardziej korzystne niż dla konsumentów. Podstawowe przyczyny są następujące: potencjalne korzyści, jakie mogą uzyskać z konsumpcji, mogą być duże w ujęciu absolutnym, lecz małe są korzyści jednostkowe. Ponadto konsumentom, ze względu na duże rozmiary tej grupy społecznej, trudno jest uporządkować preferencje dotyczące przedmiotu i form regulacji.

Swoisty rynek usług regulacyjnych dotyczy również sfery ochrony i gospodarczego korzystania ze środowiska przyrodniczego. Rynek usług regulacyjnych powstaje jako wyraz oczekiwań różnych grup interesu, polityków, urzędników administracji państwowej, firm zgłaszających popyt na regulacje, urzędów regulacyjnych i konsumentów. Regulacje ekologiczne są zatem wynikiem gry interesów pomiędzy tymi podmiotami, nie zaś wynikiem niedoskonałości rynku, niedoskonałości zwiększają bowiem możliwość regulacji. Państwo jest jednocześnie podmiotem dążącym do realizacji interesu publicznego oraz arbitrem w grze sprzecz-

\footnotetext{
${ }^{12}$ Charakterystykę przedstawiam za: B. Fiedor, Dziatania zbiorowe..., s. 37.
} 
nych interesów ekonomicznych różnych podmiotów i grup interesu ${ }^{13}$. Podobnie jak rynek, również państwo nie jest regulatorem doskonałym, zwłaszcza w odniesieniu do korzystania, ochrony i zanieczyszczania środowiska przyrodniczego.

Regulacje ekologiczne są dobrem publicznym, którego ilość i jakość kształtuje się w następstwie gry interesów i preferencji różnych podmiotów znajdujących swój wyraz $\mathrm{z}$ jednej strony $\mathrm{w}$ popycie na regulacje $\mathrm{w}$ ochronie środowiska przyrodniczego, a $\mathrm{z}$ drugiej strony w ich podaży. Wszyscy „aktorzy tej gry” dążą do maksymalizacji własnych funkcji użyteczności, a zatem dążą do osiągania korzyści politycznych, ekonomicznych, społecznych.

Podaż regulacji ekologicznych tworzona jest przez instytucje regulujące, a zatem przez parlament, rząd i jego agendy odpowiedzialne za osiąganie celów związanych z użytkowaniem i ochroną środowiska przyrodniczego, a także przez biurokrację, wykonującą powierzone jej zadania. To, czy tworzone regulacje ekologiczne są odpowiedzią na oczekiwania społeczne dotyczące jakości środowiska przyrodniczego i gospodarczego korzystania z jego zasobów, zależy od siły oddziaływania różnych grup społecznych na decyzje podejmowane przez polityków, zakresu ich niezależności oraz od tego, w jakim stopniu identyfikują się oni ze stanowiskiem poszczególnych grup społecznych.

Podaż regulacji ekologicznych zależy przede wszystkim od następujących czynników:

- celów, którymi kierują się poszczególni politycy, partie polityczne i koalicje partyjne, podejmujące lub mające wpływ na podejmowane decyzje regulacyjne,

- oczekiwań biurokracji odnośnie do korzyści z wykonywanej pracy w zakresie tworzenia konkretnych rozwiązań w zakresie ochrony środowiska przyrodniczego i gospodarowania jego zasobami,

- siły nacisków wywieranych na instytucje regulujące przez różne podmioty i grupy społeczne,

- zobowiązań wynikających z ratyfikowanych konwencji, umów i zobowiązań międzynarodowych, jak i implementacji obowiązujących w Unii Europejskiej zasad i norm prawnych dotyczących ochrony i kształtowania środowiska przyrodniczego.

W krajach demokratycznych poszczególni politycy, grupy osób tworzących partie polityczne i koalicje partyjne upatrują, w następstwie wprowadzenia określonych regulacji ekologicznych, korzyści związanych z uzyskaniem i/lub utrzymaniem władzy, a zatem tworzeniem przychylnego elektoratu i poparciem w wyborach. Obok korzyści politycznych w grę mogą wchodzić pewne korzyści ekonomiczne, takie jak możliwość podjęcia pracy w przedsiębiorstwach jako na-

${ }^{13}$ Z. Staniek, Zróżnicowanie ekonomii instytucjonalnej, http://www.e-sgh.pl/niezbednik/plik. 
grody za „przychylność" po zakończeniu kariery politycznej ${ }^{14}$. Obecnie, w sytuacji mocno akcentowanych, nagłaśnianych i powszechnie dyskutowanych problemów związanych z zanieczyszczaniem środowiska przyrodniczego i jego ochroną, politycy mogą stać się inicjatorami pewnych rozwiązań. Propagowanie nowych ekologicznych idei i wartości, które uzyskają szeroką akceptację w społeczeństwie, sprzyja tworzeniu się i wzrostowi liczebności oraz siły proekologicznego elektoratu. Dlatego też liczni politycy i grupy tworzące partie polityczne, uwzględniając preferencje różnych grup społecznych, wpisują w swoje programy wyborcze postulaty dotyczące ochrony środowiska. Skrajnym przykładem są działania „partii zielonych"15.

Rolę aparatu biurokratycznego w tworzeniu regulacji ekologicznych pomagają zrozumieć ekonomiczne modele instytucji biurokratycznych stworzone przez W. Niskanena, T. M. Moe. Zakłada się w nich indywidualizm metodologiczny (decyzje podejmują poszczególne jednostki); biurokraci wybierają rozwiązania maksymalizujące ich indywidualne korzyści (racjonalność wyboru); informacje o działaniach biurokratów są niepełne, głównie dlatego, że zazwyczaj uzyskanie takich informacji przez politycznych zwierzchników i wyborców jest kosztowne (asymetria informacji). Możliwości efektywnej kontroli działań podejmowanych przez urzędników są ograniczone ${ }^{16}$.

Zgodnie z ekonomiczną teorią regulacji, podaż regulacji ekologicznych jest odpowiedzią na zgłoszony popyt na takie regulacje. Popyt na regulacje ekologiczne mogą tworzyć:

- poszczególni producenci oraz branżowe grupy producentów; organizacje i zrzeszenia producentów i firm handlowych; grupy biznesowe upatrujące indywidualnych korzyści w określonych regulacjach,

- organy samorządowe,

- organizacje i zrzeszenia konsumentów,

- pozarządowe organizacje ekologiczne oraz ruchy ekologiczne, za które uważa się wszystkie stowarzyszenia i grupy nieformalne, które określają siebie jako „ruch”; nieformalne grupy proekologiczne zainteresowane realizacją określonych przedsięwzięć (np. zgromadzenia spontaniczne, społeczności lokalne zagrożone degradacją środowiska przyrodniczego itp.),

${ }^{14}$ Szeroko na ten temat zob. J. Buchannan, Demand and Supply of Public Goods, 1968.

${ }^{15}$ B. Fiedor, Dziatania zbiorowe..., s. 39-40.

${ }^{16}$ Taki pogląd został wyrażony w pracy: B. L. Benson, Understanding of Bureaucratic Behavior: Implications from the Public Choice Literature, "Journal of Public Finance and Public Choice” 1995, no. 8. Podaję za: P. Tłaczała, Podstawy ekonomicznej teorii biurokracji, [w:] Teoria wyboru publicznego. Wstep do ekonomicznej analizy polityki i funkcjonowania sfery publicznej, red. J. Wilkin, Wyd. Naukowe Scholar, Warszawa 2005, s. 151. 
- organizacje naukowo-badawcze zajmujące się problemami kształtowania i ochrony środowiska przyrodniczego.

\section{MIEJSCE GRUP INTERESU W KSZTAtTOWANIU REGULACJIEKOLOGICZNYCH}

Ochrona środowiska przyrodniczego i gospodarcze korzystanie z zasobów przyrodniczych są obszarami powstawania licznych konfliktów interesu wynikających z konkurencyjności celów jego użytkowników. Niektóre cele są wspólne dla wielu osób lub podmiotów gospodarczych. Wspólny interes jest przesłanką kształtowania się grup interesu i celem podejmowanych przez nie działań zbiorowych. Istnienie lub brak określonych regulacji, dotyczących ochrony środowiska przyrodniczego oraz użytkowania jego zasobów, tworzą obiektywne podstawy dla powstawania grup interesu i podejmowania przez nie działań, których celem może być wpływanie na kształt tych regulacji.

Według D. Northa w sytuacji, gdy wpływanie na reguły i ich egzekwowanie może dawać korzyści, będzie opłacało się tworzenie organizacji pośredniczących (np. grup lobbystycznych) pomiędzy podmiotami gospodarczymi a podmiotami politycznymi, aby uzyskać potencjalne korzyści ze zmian politycznych ${ }^{17}$. Praktyka pokazuje, że przedsiębiorstwa, korporacje, branżowe grupy interesu, zainteresowane określonymi decyzjami państwa w zakresie ochrony środowiska przyrodniczego i korzystania $\mathrm{z}$ jego zasobów, często korzystają z usług grup prowadzących działalność lobbingową, uznając ją za skuteczniejszą niż bezpośrednie angażowanie się w wywieranie nacisku.

Ekonomiczną analizę grup interesu zawdzięczamy, przede wszystkim, M. Olsonowi, zwłaszcza koncepcji przedstawionej w pracy The Logic of Collective Action ${ }^{18}$. Podstawą metody badawczej grup interesu są przyczyny i skutki działań zbiorowych. Celem powstawania grup interesu jest racjonalna maksymalizacja korzyści prywatnych. Jednostki podejmują działania autonomiczne i mają na celu interes własny, ich wybory są racjonalne, a swobodę wyborów określają instytucje tworzone przez państwo. U podstaw działań zbiorowych leży zatem interes własny członków grupy. Poszczególne osoby podejmują decyzję wejścia do grupy, jeżeli oczekiwane indywidualne korzyści z działań zbiorowych będą większe od kosztów związanych z przystąpieniem. Według Olsona celem działań zbiorowych

${ }^{17}$ D. North, Institutions, institutional change and economic performance, Cambridge University Press, Cambridge 1990, s. 87.

${ }^{18} \mathrm{~W}$ literaturze ekonomicznej znajdujemy kilka koncepcji wyjaśniających istotę grup interesu: pluralistyczna koncepcja grup interesu A. F. Bentleya i D. B. Trumana, koncepcja G. S. Beckera, teoria działań zbiorowych M. Olsona oraz model regulacji G. J. Stiglera. 
grup interesu jest dostarczanie dobra publicznego, z którego korzystają członkowie grupy, podejmujący wspólne działania i ponoszący koszty uzyskania tegoż dobra. W przypadku braku lub ograniczonych możliwości wyłączenia mogą pojawić się osoby pasożytujące na wysiłku innych (free-riding). Grupy interesu, chcąc się ustrzec przed zjawiskiem ,jazdy na gape”, mogą stosować bodźce selektywne, które mogą być bodźcami pozytywnymi (nagrody, wyróżnienia, pochwały itp.) lub bodźcami negatywnymi (wykluczenia, kary itp.). Olson wskazuje, że w wyniku działania grupy mogą być dostarczane dobra, z których mogą korzystać zarówno członkowie danej grupy, jak i całe społeczeństwa ${ }^{19}$.

Grupę interesu w sferze ochrony i użytkowania środowiska przyrodniczego tworzą jednostki, które podejmują wspólne działania na rzecz realizacji wspólnego interesu. Grupy te mają następujące cechy:

- celem działań zbiorowych grup interesu jest dostarczanie dobra grupowego, między innymi korzystnych dla członków grupy regulacji w zakresie ochrony i użytkowania środowiska przyrodniczego,

- reprezentują interesy członków grupy wobec innych grup oraz podejmuja działania, które stanowią ich ochronę przed działaniami innych grup lub przed niekorzystnymi zdarzeniami społecznymi, ekonomicznymi czy prawnymi,

- pośredniczą w przekazywaniu postulatów członków grupy ośrodkom decyzyjnym oraz mogą wpływać na opinię publiczną, rząd i parlament, zatem mogą wpływać na kierunki rozwiązań regulacyjnych.

Zainteresowanych ochroną i korzystaniem ze środowiska przyrodniczego, którzy są potencjalnymi uczestnikami działań zbiorowych w tym obszarze, można podzielić w następujący sposób ${ }^{20}$ :

1) podmioty gospodarcze, dla których korzystanie ze środowiska przyrodniczego jest istotnym czynnikiem warunkującym działalność gospodarczą oraz znaczącym składnikiem ich funkcji użyteczności,

2) poszczególne osoby i grupy społeczne, dla których środowisko przyrodnicze jest wartością samą w sobie, zatem zainteresowane są jego ochroną i racjonalnym gospodarowaniem jego zasobami,

3) poszczególne osoby i grupy osób wykorzystujące własną aktywność w ochronie środowiska jako środek do osiągnięcia innych celów, dla uzyskania indywidualnych korzyści materialnych, społecznych, politycznych (regulacje są „produktem ubocznym”).

${ }^{19}$ M. Olson, The Logic of Collective Action. Public Goods and the Theory of Groups, Harvard University Press, Cambridge 1965.

${ }^{20}$ Szerzej na ten temat: I. Rumianowska, Grupy interesu i grupy nacisku w ochronie środowiska, referat na konferencję naukową pt. „Ekonomia instytucjonalna w Polsce. Doświadczenia i przyszłość”, UE, Wrocław, 17-18 listopada 2008. 
Kryterium stosunku do środowiska przyrodniczego i sposobu korzystania z jego zasobów pozwala na dokonanie podziału wszystkich zainteresowanych grup społecznych i podmiotów gospodarczych na dwa zasadnicze typy: nieekologiczne grupy interesu - grupy producentów, grupy biznesowe, organizacje producentów i firm handlowych, które przedkładają realizację celów ekonomicznych (przede wszystkim - maksymalizację zysku) nad cele ekologiczne (środowisko przyrodnicze traktowane jest instrumentalnie); proekologiczne grupy interesu organizacje i grupy społeczne chcące mieć wpływ na politykę ekologiczną państwa i kształtowanie przyjaznych środowisku przyrodniczemu postaw i zachowań społecznych $^{21}$.

Korzyści, jakie może osiągnąć jednostka z przynależności do grupy interesu, mogą należeć do następujących kategorii: 1) materialne, dające wyrazić się zazwyczaj w formie pieniężnej, 2) grupowe-społeczne, wynikające $z$ uczestnictwa w działalności grupy, 3) celowe-społeczne, wynikające $z$ ideologicznych lub zadaniowych celów grupy niezwiązanych ze znaczącym zyskiem dla członków grupy $^{22}$.

Celem środowisk gospodarczych są przeważnie korzystne regulacje prawno-administracyjne lub, rzadziej, ekonomiczno-rynkowe, dotyczące sposobu i skali korzystania danej branży lub sektora gospodarki z usług środowiska przyrodniczego i jego zasobów. Popyt na określone regulacje ekologiczne wynika z oczekiwania następujących korzyści: ograniczenie kosztów wynikających z gospodarczego użytkowania środowiska przyrodniczego i jego zasobów (powiększanie zysku); osiąganie korzyści wynikających z ograniczenia wejścia do danej branży potencjalnych konkurentów; zagwarantowania swobody w kształtowaniu cen (przede wszystkim utrzymania ich na wyższym poziomie) lub ich kontroli; zagwarantowania ochrony przed konkurencją ze strony firm z krajów, gdzie regulacje ekologiczne są łagodniejsze i mniej restrykcyjne; uzyskanie subsydiów lub ulg podatkowych; otrzymanie koncesji lub przywilejów przetargowych; czasami uzyskanie wyłączenia $z$ danej regulacji. Poszczególni producenci oraz grupy przedsiębiorstw, zgłaszając popyt na określone regulacje ekologiczne, mogą mieć na celu osiągnięcie przewagi konkurencyjnej na rynku (obecnie lub w przyszłości) w wyniku innowacyjnych rozwiązań dostępnych tylko dla nich.

Olson zauważył, że grupy interesu związane z biznesem, charakteryzując się niewielkimi rozmiarami (grupy małe lub średnie) oraz łatwością i skutecznością podejmowanych działań, mogą uzyskać dla poszczególnych branż lub grup przedsiębiorstw korzystne rozwiązania, wygrywając rywalizację z innymi grupami społecznymi w zakresie wywierania wpływu na polityków. Wysoki stopień zor-

${ }^{21}$ Ibidem.

${ }^{22}$ P. A. Sabatier, Przynależność do grup interesów a ich organizacja: przegląd teorii, [w:] J. Szczupaczyński (red.), Wtadza i spoteczeństwo, Wyd. Naukowe Scholar, Warszawa 1995, s. 201. 
ganizowania grup biznesowych oraz ich zdolność wywierania nacisku na organy władzy publicznej ma często związek z niewielką liczbą firm w danej branży (oligopolistycznymi strukturami wielu przemysłów) ${ }^{23}$. Powyższe spostrzeżenie znajduje swoje potwierdzenie w odniesieniu do działań grup związanych z przemysłem w obszarze ochrony środowiska przyrodniczego i gospodarowania jego zasobami, gdzie grupy interesu starają się uzyskać korzystne dla siebie regulacje, poprzez zorganizowany lobbing, oferowanie usług w zakresie doradztwa i wiedzy eksperckiej, stabilności kontaktów z organami władzy wykonawczej, bezpośrednie kontakty z politykami, mobilność między sektorem publicznym a grupami interesu, wreszcie oferowanie korzyści materialnych.

Cele ekologiczne o charakterze społecznym realizowane są przede wszystkim, przez organizacje i grupy proekologiczne. Grupy zainteresowane ochroną środowiska i racjonalnym gospodarowaniem jego zasobami mogą dążyć do dostarczenia dobra publicznego w postaci regulacji ekologicznych, poprzez wywieranie nacisku na centrum decyzyjne lub na społeczeństwo. Znamiona bezpośredniego nacisku na centrum decyzyjne ma opiniowanie projektów ustaw i innych regulacji w zakresie ochrony i kształtowania środowiska przyrodniczego oraz działalność lobbingowa, współpraca $\mathrm{z}$ agendami rządowymi, podejmowanie działań interwencyjnych, bezpośrednie działania, np. manifestacje, akcje protestacyjne, blokady, pikiety i inne spektakularne formy działań. Metody działań organizacji ekologicznych i grup wspierających często są niekonwencjonalne, czasami pozostają na granicy legalności, czego przykładem mogą być akty cywilnego nieposłuszeństwa.

Organizacje ekologiczne i inne proekologiczne grupy społeczne swoje cele społeczne realizują za pomocą różnych form działań, takich jak: wykłady, szkolenia i kursy dotyczące problemów ochrony środowiska przyrodniczego, seminaria, konferencje, spotkania mające na celu wymianę poglądów i doświadczeń, publikacje prasowe, programy radiowe i telewizyjne, strony internetowe, a także współpraca z innymi organizacjami społecznymi, stowarzyszeniami, fundacjami, samorządami terytorialnymi.

Czasami organizacje ekologiczne lub nieformalne grupy społeczne działające na rzecz ochrony środowiska przyrodniczego potrafią skuteczniej, niż np. organizacje przemysłowe, zmobilizować swoich członków oraz skłonić ich do podjęcia określonych działań (nawet nielegalnych), aby w ten sposób wpływać na opinię publiczną i wywrzeć wpływ na decyzje władz np. odnośnie do lokalizacji uciążliwej środowiskowo inwestycji (np. składowiska lub spalarni śmieci, oczyszczalni ścieków, budowy drogi, zapory wodnej, elektrowni jądrowej itp.). Często większą „siłę przetargową" mają grupy interesu działające w skali lokalnej. Ich naciski na władze samorządowe charakteryzują się relatywnie dużą skutecznością.

${ }^{23}$ M. Olson, op. cit., s. 143-148. 
Skuteczność działań grup interesu w sferze ochrony środowiska przyrodniczego zależy od wykorzystania odpowiednich strategii i środków wywierania wpływu na władze centralne czy samorządowe. Zwykle wszystkie grupy interesu starają się najpierw bezpośrednio dotrzeć ze swoimi postulatami do odpowiednich władz, a gdy działania lobbingowe, bezpośrednie kontakty i rozmowy z władzami nie dają pozytywnych rezultatów, poszukują wsparcia mass mediów oraz mobilizują członków swojej grupy do udziału w protestach i akcjach informacyjno-perswazyjnych skierowanych do szerokich kręgów społecznych.

\section{ECOLOGICAL REGULATIONS AND INTEREST GROUPS IN PROTECTION OF NATURAL ENVIRONMENT}

SUMMARY

Explanation of ecological regulation can be based on the normative theory of regulation or on the economic theory of regulation, which came into being on the basis of the new institutional economy. A common feature of all theories of regulation is the assumption that a country's assistance in the market's coordination role is necessary also in the field of protection of the natural environment. The normative theory of regulation justifies the necessity of regulating markets from the imperfections of the market mechanism. The economical theory of regulation treats state regulations as a specific market of regulation services also in the field of protection and usage of the natural environment. This market emerges to satisfy the expectations of various interest groups, politicians, administrative officials, companies demanding such regulations, regulation agencies and consumers. Ecological regulations are the result of the play of interests between subjects demanding regulations (particular producers, manufacturers, groups of trade producers, business organizations, ecological organizations, consumers organizations, etc.) and the supply (created by particular politicians, political parties and party coalitions as well as bureaucracy), although it is granted that each subject is concerned with maximizing benefits.

The fundamental influence on raising ecological regulations has interest groups interested in the implementation of regulations which give them particular benefits. 